\title{
Anterior boundaries of Hox gene expression in mesoderm-derived structures correlate with the linear gene order along the chromosome
}

\author{
Gregory R. Dressler and Peter Gruss * \\ The Max Planck Institute for Biophysical Chemistry, D-3400 Göttingen, Federal Republic of Germany
}

\begin{abstract}
The developmental expression patterns of four genes, Hox 1.1, Hox 1.2, Hox 1.3 and Hox 3.1, were examined by in situ hybridization to serial embryonic sections. The three genes of the Hox 1 cluster, used in this study, map to adjacent positions along chromosome 6 , whereas the Hox 3.1 gene maps to the Hox 3 cluster on chromosome 15 . The anterior expression limits in segmented mesoderm varied among the four genes examined. Interestingly, a linear correlation exists between the position of the gene along the chromosome and the extent of anterior expression. Genes that are expressed more posterior are also more restricted in their expression in other mesoderm-derived tissues. The order of expression anterior to posterior was determined as: Hox 1.3, Hox 1.2, Hox 1.1 and Hox 3.1. Similarly, genes of the Drosophila Antennapedia and Bithorax complex specifying segment identity also exhibit anterior expression boundaries that correlate with gene position. The data suggest that Hox genes may specify positional information along the anterior-posterior axis during the formation of the body plan.
\end{abstract}

\section{Introduction}

The discovery that a conserved protein domain, the homeobox, is present not only in several homeotic genes of Drosophila $[38,45]$ but also in numerous genes of higher eukaryotes quickly led to the isolation and characterization of many different mammalian genes potentially important for developmental regulation $[3,6,25,31,36,39]$. The homeotic genes of Drosophila determine the fate of individual body segments by specifying positional information during embryogenesis (for reviews see [1, 20-22, 44]. That mammalian homeobox-containing genes also are controlling factors required for the physical determination of the body plan has not been demonstrated, primarily because mutations in the respective loci are lacking. However, much information regarding potential function of homeobox-containing genes can be obtained by spatial and temporal expression analysis in developing embryos.

During the process of murine embryogenesis, many developing tissues, and the central nervous system in particular, transcribe one, or more, homeobox-containing gene. In fact, all Hox 1, Hox 2, and Hox 3 genes studied to date are transcribed in a tissue-specific manner in adults and developing embryos (for review see $[10,29]$ ). Maximum lev-

\footnotetext{
* To whom offprint requests should be sent
}

els of Hox 1.1 transcripts are detected in RNAs from embryos at $\mathbf{1 2}$ days post coitum (p.c.) and multiple transcripts are found in adult testis, kidney, brain, and ovary [7]. Restricted transcription of the Hox 1.3 gene to thoracic sclerotomes, as well as tissues derived from or induced by thoracic mesoderm, was the first indication that a murine homeobox gene may encode positional information along the rostralcaudal axis [9]. Transcripts of the Hox 1.5 gene are expressed in mesoderm and ectoderm of 7- to 9-day p.c. embryos, but are spatially restricted to the ectoderm-derived neural tube, myencephalon, dorsal root ganglia and many mesoderm-derived tissues including the prevertebrae at 11 days p.c. and later $[13,16,18,19]$. Hox 1.2 is also transcribed in the developing nervous system, as well as some thoracic sclerotomes [19, 47]. The Hox 2.1 gene [33], which shares many sequence similarities with the Hox 1.3 gene $[14,42]$, is transcribed in a pattern similar to the Hox 1.3 gene in embryonal tissues such as lung, stomach, mesenephros, hindbrain, and neural tube, but is not expressed in thoracic sclerotomes [28]. Transcripts in the embryonal neural tube also have been shown with the Hox 1.4 gene [11, 49], the Hox 3.1 gene [2, 5, 35, 48], the Hox 6.1 gene [46], the Hox 2.3 gene [40], the Hox 2.6 gene [23] and other genes of the Hox 2 cluster [24]. In order to more-precisely determine the physical expression boundaries between the genes of a cluster and the potential overlap of expression among genes, a direct comparison of Hox gene expression was undertaken to provide supportive data for the hypothesis that homeobox genes specify positional information.

With the onset of somitogenesis in the mesoderm of early vertebrate embryos, a segmented pattern of somites is generated parallel to the rostral-caudal axis, on either side of the neural tube. At this point in development, the organism can be considered segmented (for review see [26]). A variety of different tissues, including, ribs vertebrae, muscle, and skin, are derived directly from the differentiating somites. In addition, inductive interactions between somites and neighboring ectoderm generates the metameric dorsal root ganglia (for review see [32]) and sympathetic ganglia. How this segmented pattern is generated and how segment position along the anterior-posterior axis is specified are key questions in developmental biology that remain to be answered.

This report presents a comparative analysis of the Hox 1.1, 1.2, 1.3, and 3.1 transcripts beginning at the earliest developmental stages when RNA first can be detected by in situ hybridization. These four genes are of particular interest with regard to specifying the identity of body seg- 
ments, as they are all expressed in the somite-derived sclerotomes and restricted to the thoracic region. Furthermore, Hox 1.1, 1.2, and 1.3 are closely linked on chromosome 6 and contain homeoboxes of the Antennapedia class, as does Hox 3.1. Using serial sections of embryos, in situ hybridization data clearly shows unique patterns of transcript accumulation for each of the $\operatorname{Hox} 1.1,1.2,1.3$, and 3.1 genes. In the sclerotomes of the 12-day p.c. embryo, there is an increasing level of restriction in the number of positive sclerotomes and in the anterior boundry of sclerotome expression. The order of expression in the thoracic sclerotomes, rostral to caudal, is $\operatorname{Hox} 1.3,1.2,1.1$, and 3.1 respectively and correlates with the linear order of genes along the chromosome. In addition, the level of transcript restriction is seen in tissues derived from the embryonic mesoderm. Similar results have also been reported by Gaunt et al. [19] with the $\operatorname{Hox} 1.4,1.3,1.2,6.1$ and 3.1 genes.

\section{Methods}

Animals. To isolate mouse embryos at various stages p.c., NMRI outbred mice, living on a light-dark cycle of $12 \mathrm{~h}$, were paired in the evening and checked for vaginal plugs the next morning. The morning after successful mating was approximated as 0 days p.c. For the early postimplantation embryos, days 6-9, the deciduum was disected out of the uterus and frozen intact for sectioning. Beginning at day 10, embryos were disected free of extraembryonic tissues and frozen intact. All sections were cut at $-20^{\circ} \mathrm{C}$ and $8 \mu \mathrm{m}$ in a cryostat, transferred onto subbed slides [15], fixed in $4 \%$ paraformaldehyde (PFA) and dehydraded in graded ethanol.

RNA probes. Fragments containing either genomic or cDNA sequences were subcloned into the vectors pSPT18/ 19 (Pharmacia) and linearized with restriction endonuclease. Single-stranded RNA probes were transcribed in vitro using $100 \mu \mathrm{Ci}^{35} \mathrm{~S}-\mathrm{UTP}$ and SP6 or T7 polymerases (Promega Biotech, Heidelberg, FRG). After DNAse digestion, probes were precipitated with $10 \%$ trichloroacetic acid and collected on nitrocellulose filters (Millipore, Eschborn, FRG). Probes were eluted from the filters in $20 \mathrm{mM}$ EDTA, pH $8.0,0.1 \%$ sodium dodecyl sulfate (SDS) at $65^{\circ} \mathrm{C}$. Following ethanol precipitation, probes were partially degraded with $0.2 \mathrm{~N} \mathrm{NaOH}$ on ice for 30-60 min and neutralized with $1 M$ acetic acid. After ethanol precipitation, the probes were resuspended in $50 \%$ formamide, $10 \mathrm{~m} M$ dithiotrectol (DTT).

In situ hybridization. Sections were prepared and hybridized essentially as described by Hogan et al. [27] with modifications by Dony and Gruss [9]. Slides were kept at $-20^{\circ} \mathrm{C}$ until the day of hybridization. Slides were dipped in phosphate buffered saline (PBS) and incubated at $70^{\circ} \mathrm{C}$ in $2 \times$ SSC (standard saline citrate). After a second PBS rinse, slides were digested with $0.125 \mathrm{mg} / \mathrm{ml}$ pronase for $10 \mathrm{~min}$ at room temperature and the digestion was stopped in $0.2 \%$ glycine for $30 \mathrm{~s}$. Slides were rinsed in PBS and refixed in 4\% paraformaldehyde (PFA) for 20 min and rinsed again in PBS. Slides were acetylated in $0.1 \mathrm{M}$ triethanolamine with 1/400 vol acetic anhydride, made fresh. Slides were rinsed again in PBS and dehydraded in graded ethanol. After prolonged air drying, the hybridization mixture was added. The probe was diluted to approximately $5 \times 10^{4} \mathrm{cpm} / \mu \mathrm{l}$ in a buffer containing $50 \%$ formamide, $0.3 M \mathrm{NaCl}, 10 \mathrm{~m} M$ Tris, $10 \mathrm{mM} \mathrm{NaPO}{ }_{4}$ (pH 6.8), $5 \mathrm{mM}$ EDTA, $1 \times$ Denhardts, $10 \%$ dextran sulphate, $10 \mathrm{mM}$ DTT, and $1 \mathrm{mg} / \mathrm{ml}$ tRNA. The hybridization mix was boiled for $2 \mathrm{~min}$, applied directly onto sections and covered with a siliconized cover slip. Hybridization was done overnight in a humid chamber at $50^{\circ} \mathrm{C}$. Washing was done for $3-4 \mathrm{~h}$ in $50 \%$ formamide, $2 \times \mathrm{SSC}$ at $37^{\circ} \mathrm{C}$ followed by RNAse digestion [30]. A second wash in 50\% formamide, $2 \times$ SSC was done overnight and the slides were then dehydraded in graded ethanol.

Autoradiography. Slides were dipped in Kodak NTB-2 emulsion diluted 1:1 with water and allowed to dry in a dark chamber for $2-3 \mathrm{~h}$. Slides were placed in a dark plastic box, wrapped in foil, and allowed to expose for 6-10 days. Development was done at room temperature for $3 \mathrm{~min}$ in

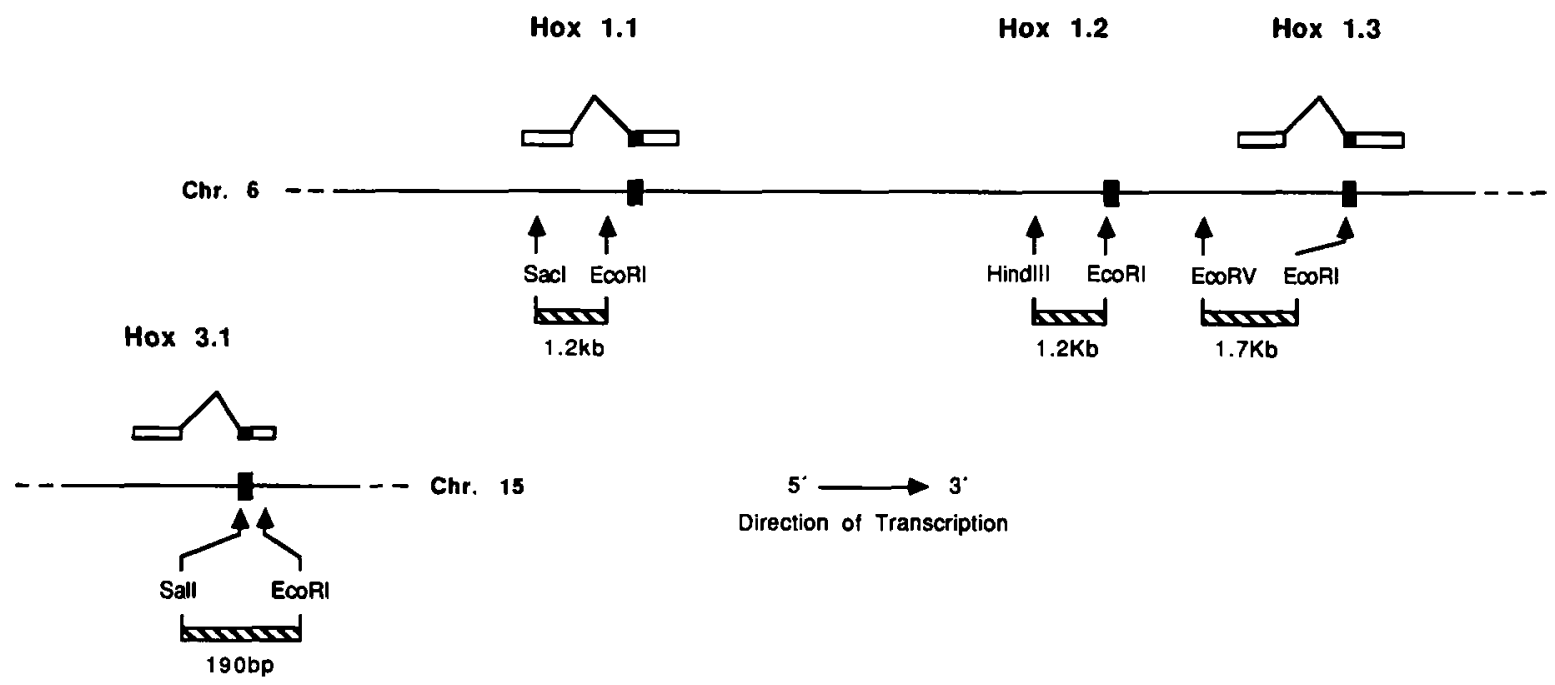

Fig. 1. The genomic organization of $\operatorname{Hox} 1.1,1.2,1.3$ and 3.1. The homeoboxes are shown in solid black, whereas the mRNAs are shown as open rectangles. The probes used for in situ hybridization are representcd in the striped rectangles. The direction of transcription is indicated 


\section{Hox 1.3}
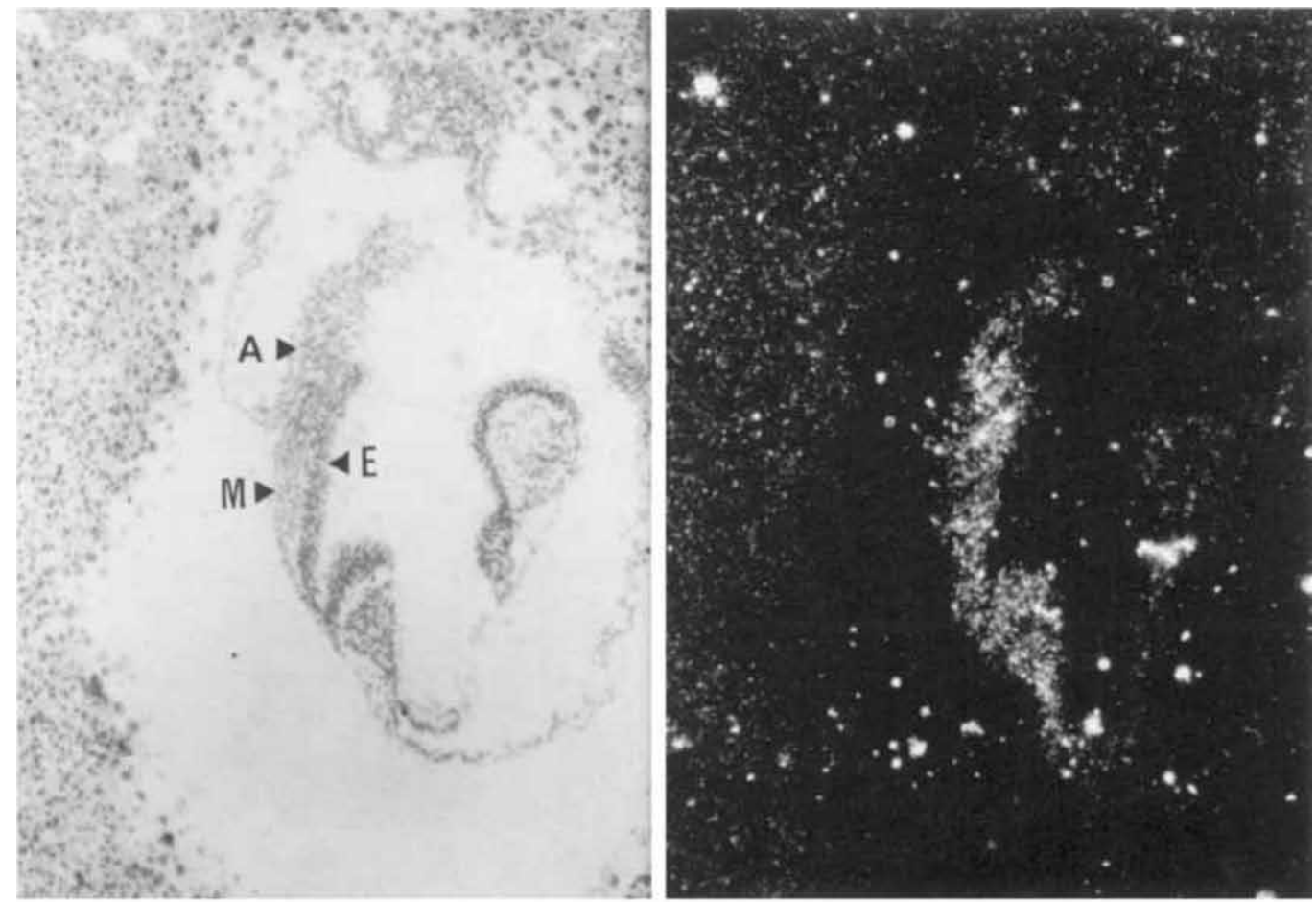

$\operatorname{Hox} 1.2$

Hox 1.1
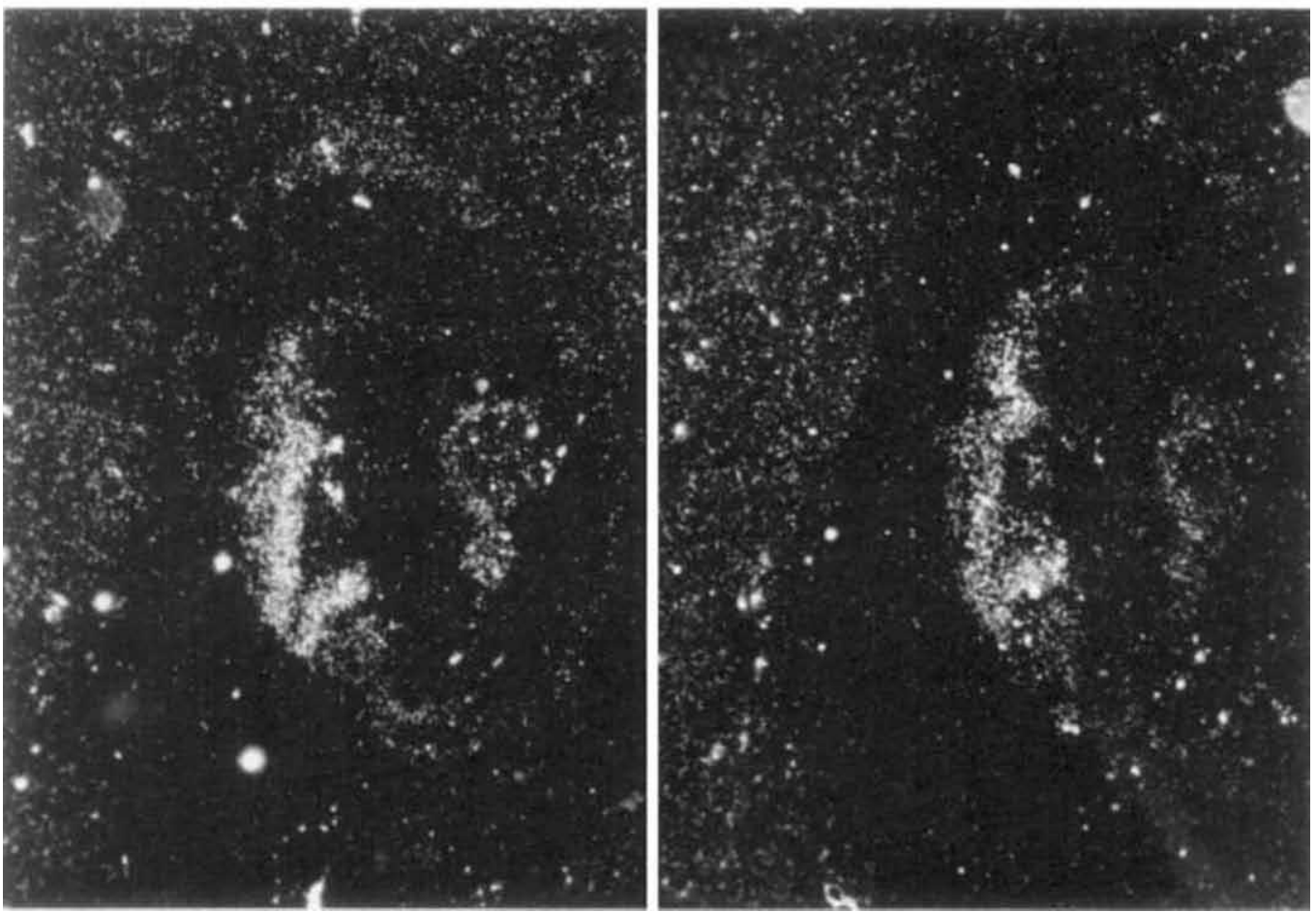

Fig. 2. In situ hybridization to 8-day embryos. A bright-field image of a transverse section is shown; mesoderm ( $M$ ), ectoderm (E) and the base of the allantois $(A)$ are indicated. Subsequent dark-field images of serial sections hybridized with the indicated probes are also shown

Kodak D-19, followed by $30 \mathrm{~s}$ in $1 \%$ acetic acid and $3 \mathrm{~min}$ in $30 \%$ sodium thiosulphate. After repeated washes in distilled water, the slides were stained with Giemsa and allowed to dry. Photomicrographs were taken with a Leitz Labovert brightfield/darkfield microscope.

\section{Results}

The probes corresponding to the homeobox genes used in this study are outlined in Fig. 1. On chromosome 6, the Hox 1 cluster consists of at least seven genes of which six 
Hox 1.3

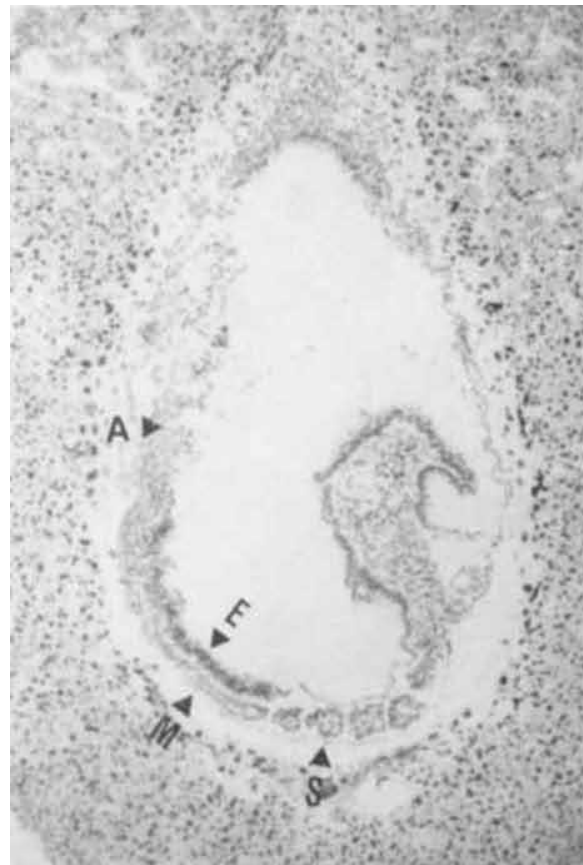

Hox 1.1

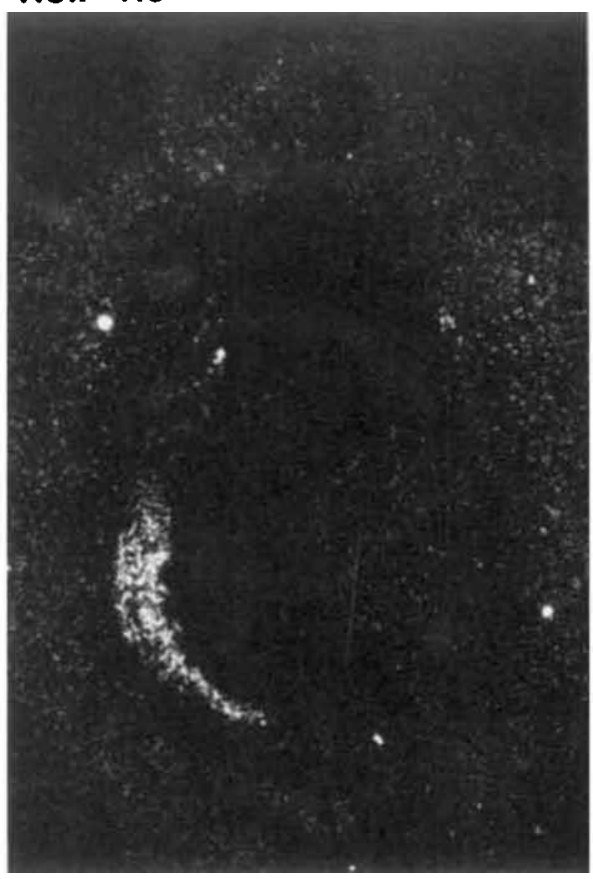

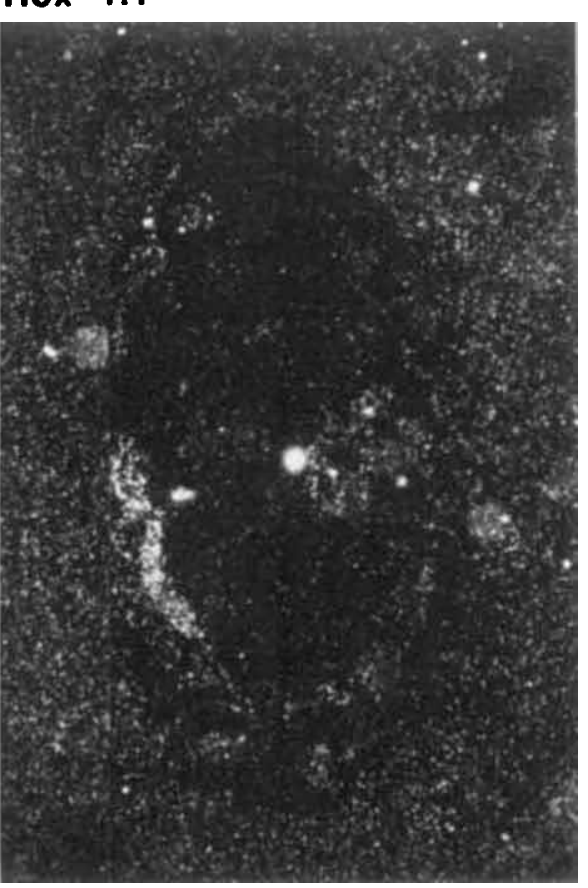

Fig. 3. In situ hybridization to 8-day embryos. Sagital sections were hybridized with the indicated probes. Indicated are the mesoderm ( $M$ ), ectoderm $(E)$, somites $(S)$, and the base of the allantois $(A)$

are physically linked $[3,7,11]$. Shown in Fig. 1 are the genes $\operatorname{Hox} 1.1,1.2$ and 1.3. The genes $\operatorname{Hox} 1.4,1.5$ and 1.6 are located ' 3 ' to Hox 1.3 along the cluster. The direction of transcription is the same for all genes in a cluster. Also shown is the Hox 3.1 gene on chromosome 15. The Hox 3.1 gene belongs to a subfamily whose Hox 1 homology would lie $5^{\prime}$ to $H o x 1.1$ [12]. The Hox 1.1 probe is a $1.2-\mathrm{kb}$ EcoRISacI fragment containing the entire first exon and part of the intron [34]. The Hox 1.2 probe is a $1.2-\mathrm{kb}$ EcoRIHindIII fragment that contains approximately $60 \mathrm{bp}$ of homeobox sequence and extends $1.1 \mathrm{~kb}$ upstream. Although the Hox 1.2 transcript has not been mapped, it is clear that this probe recognizes a transcript different from Hox 1.1 or Hox 1.3, as the data will show. The Hox 1.3 probe is a 1.7-kb EcoRV-EcoRI fragment, obtained from a cDNA clone [14], and contains $34 \mathrm{bp}$ of homeobox sequence. The Hox 3.1 probe is a 190 bp Aval-Sall fragment that contains mostly homeobox sequences [5], however the probe does not cross-hybridize to other homeobox transcripts under the conditions used. The RNA probes were labeled with ${ }^{35}$ S-UTP and SP6 or T7 polymerases and partially degraded to a size range of 50-150 nucleotides to facilitate optimum hybridization. Both the sense and antisense strands of all the probes were hybridized to serial sections to rule out any nonspecific binding of the probes. With all four genes, the sense probes did not hybridize specifically to any tissues (data not shown).

In order to determine the earliest embryonic stages when Hox transcripts could first be detected, sections from 6,7 , 8 , and 9 days p.c. embryos were hybridized with the Hox 1.1, 1.2, and 1.3 probes. None of the probes used showed any specific hybridization to 6- or 7-day p.c. embryos (data not shown). However, beginning at the stage when the head fold can be easily distinguished, approximately 8 days p.c., transcripts corresponding to the
Hox 1.1, 1.2, and 1.3 genes can be detected by in situ hybridization, as shown in Fig. 2. Positive hybridization to posterior ectoderm can be seen with all three probes at this time. At 8 days p.c., closure of the neural tube proceeds from the middle of the embryo towards the anterior and posterior ends. It is evident that Hox gene transcript can be detected in neural ectoderm prior to closure at the posterior end. $\operatorname{Hox} 1.1$ and $H o x 1.2$ can be detected in neural ectoderm and at the base of the allantois at this stage. The Hox 1.3 transcripts can be detected in ectoderm and presomitic mesoderm, where the transcripts are more caudal with respect to ectodermal transcripts. This is most clearly illustrated in Fig. 3. Similar sections hybridized with Hox 1.1 show low levels of transcripts in ectoderm, but do not show detectable embryonic mesoderm transcripts, although transcripts can be detected in the mesoderm derived allantois.

The three genes of the Hox 1 cluster show different anterior expression boundaries in segmented mesoderm. Although the pattern is fixed earlier, it becomes clearly evident at day 11. Frontal sections are shown in Fig. 4, hybridized with $\operatorname{Hox} 1.1,1.2$, and 1.3. Clearly the expression pattern of $H o x 1.3$ extends furthest anterior in the prevertebrae. Expression of $\operatorname{Hox} 1.2$ begins approximately four to five segments posterior, and $\operatorname{Hox} 1.1$ is still another segment further posterior. Expression can also be detected in the neural tube for all three genes. It is of interest to note that $H o x$ gene expression is maximum in the ribs and rib homologues of the developing vertebrae. The vertebrae centrum, centered around the notochord, does not show high levels of Hox gene transcripts.

Sagital sections taken at 12 days of gestation show not only differences in anterior prevertebrae expression boundaries but also differences in other mesoderm-derived tissues (Fig. 5). Again, expression of Hox 1.3 is most anterior, with 


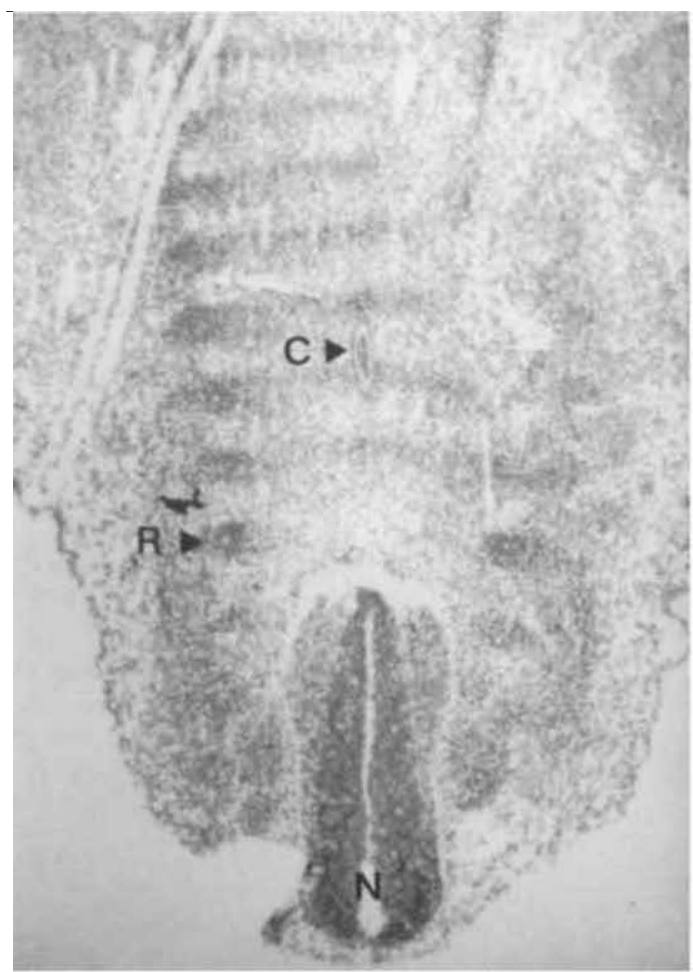

\section{Hox 1.3}

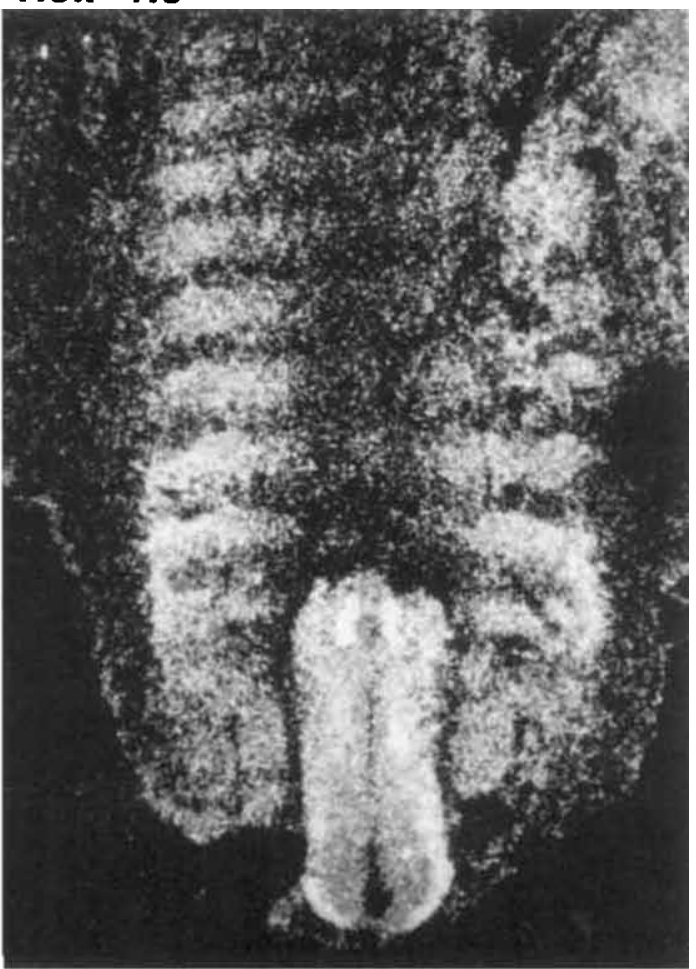

\section{$\operatorname{Hox} 1.2$}

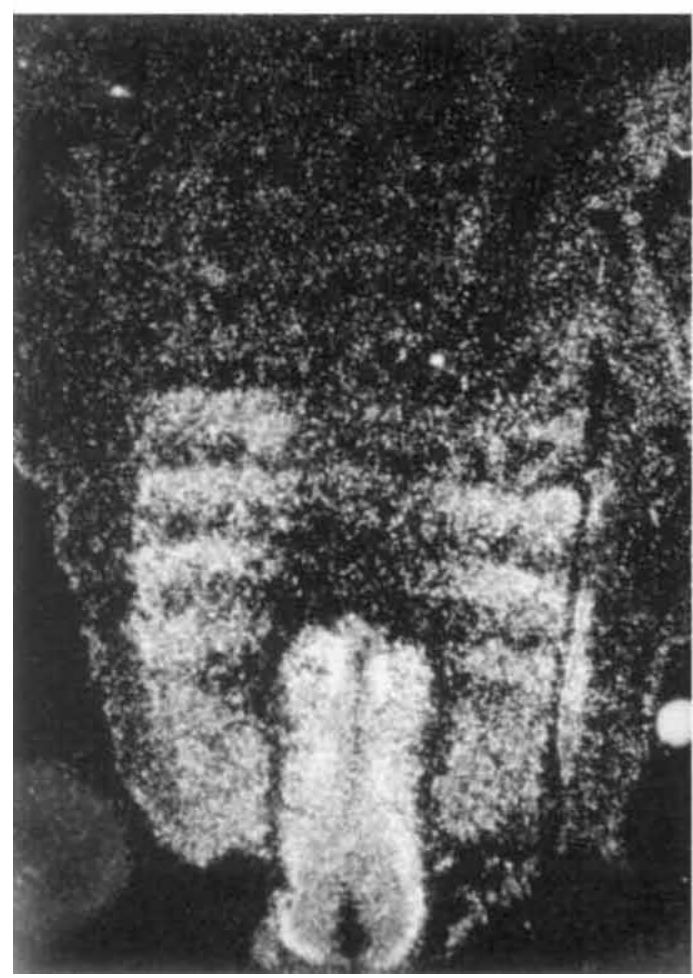

Hox 1.1

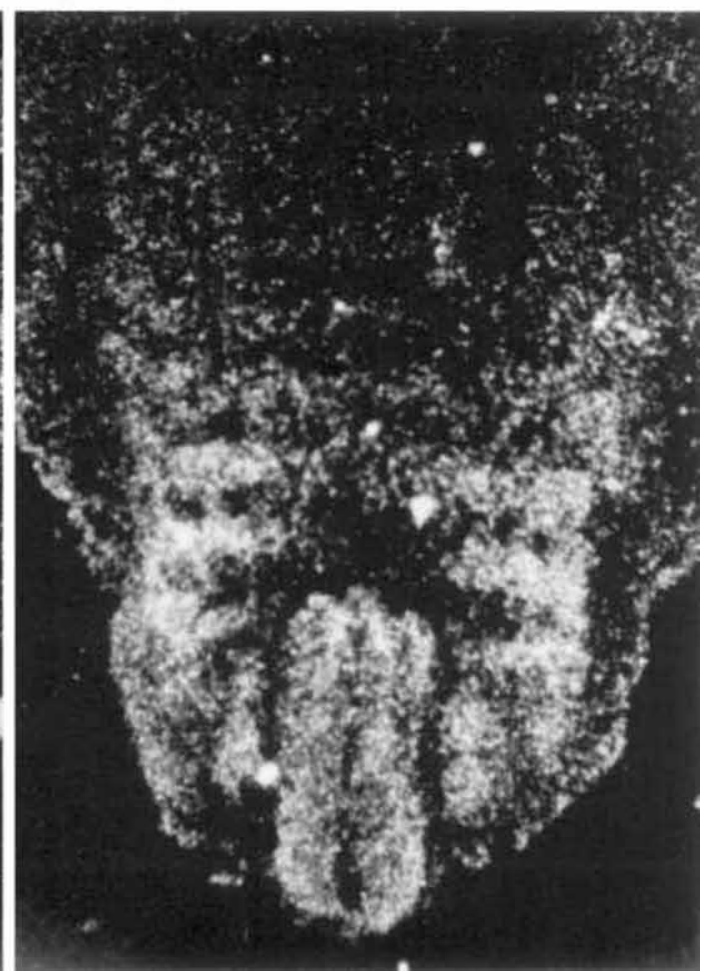

Fig. 4. In situ hybridization to frontal sections of an 11-day embryo showing the neural tube $(N)$, notochord $(C)$ and ribs $(R)$. A bright-field image and three dark-field images of serial sections, hybridized with the respective probes, are shown; anterior is up

low levels of expression beginning at the third cervical prevertebrae. Hox 1.3 transcript levels increase as the first thoracic prevertebrae is approached. Tissues such as lung, stomach, metanephros, and intestines also express Hox 1.3. Expression of Hox 1.2 in prevertebrae is approximately four segments posterior to the Hox 1.3 expression boundary, with weak signals detected in the first thoracic prevertebrae and subsequently strong signals seen in the second thoracic prevertebrae. Interestingly, Hox 1.2 is expressed in all tissues that express $\operatorname{Hox} 1.3$ with the exception of the lung 
$\operatorname{Hox} 1.3$

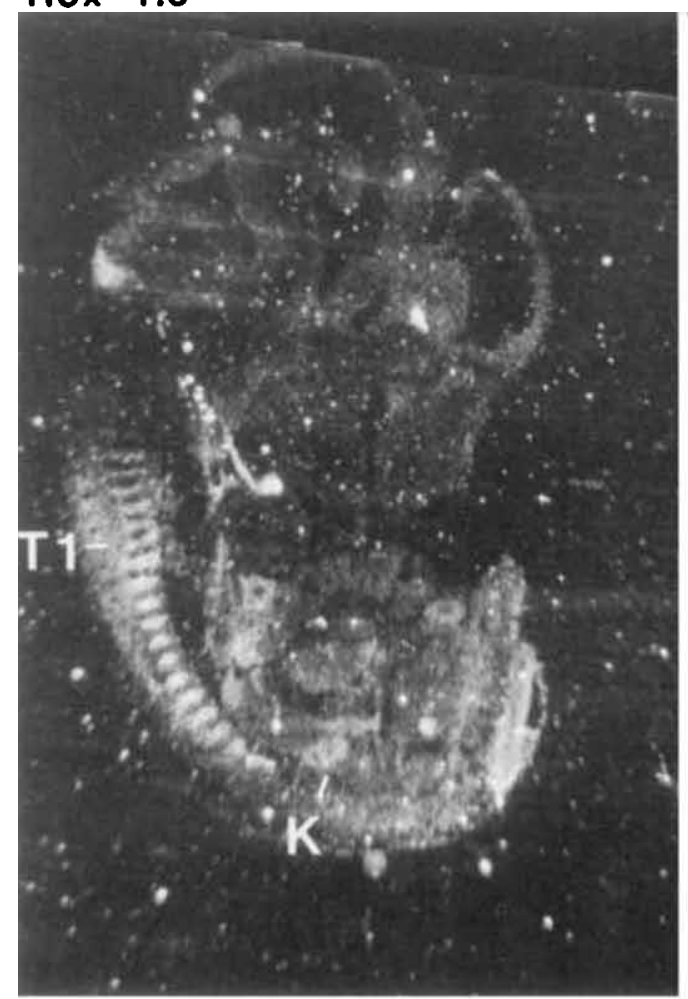

Hox 1.1

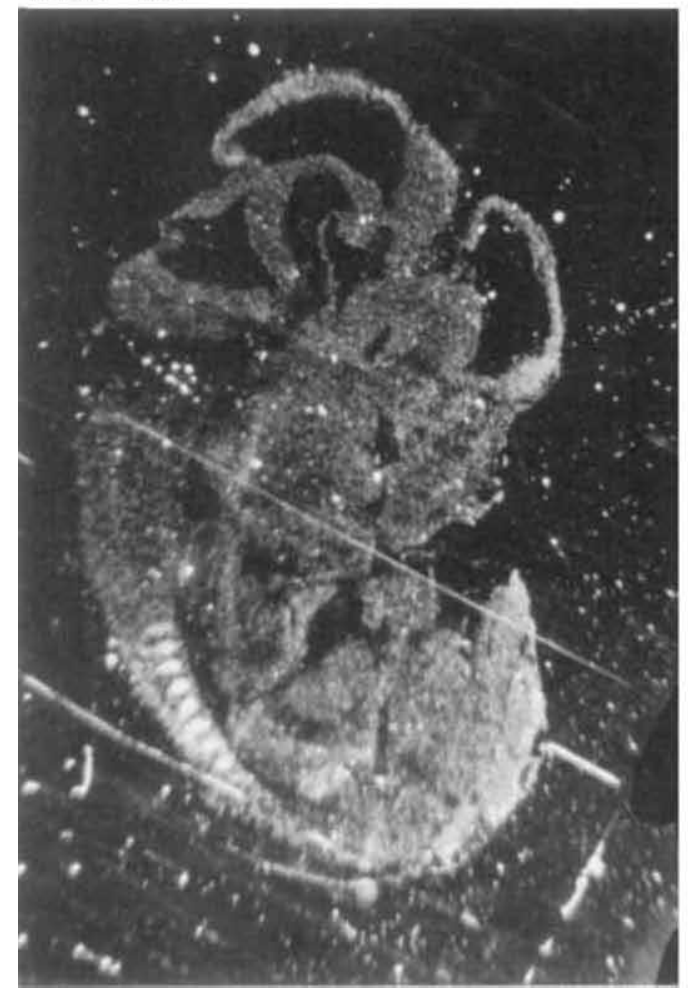

Hox 1.2

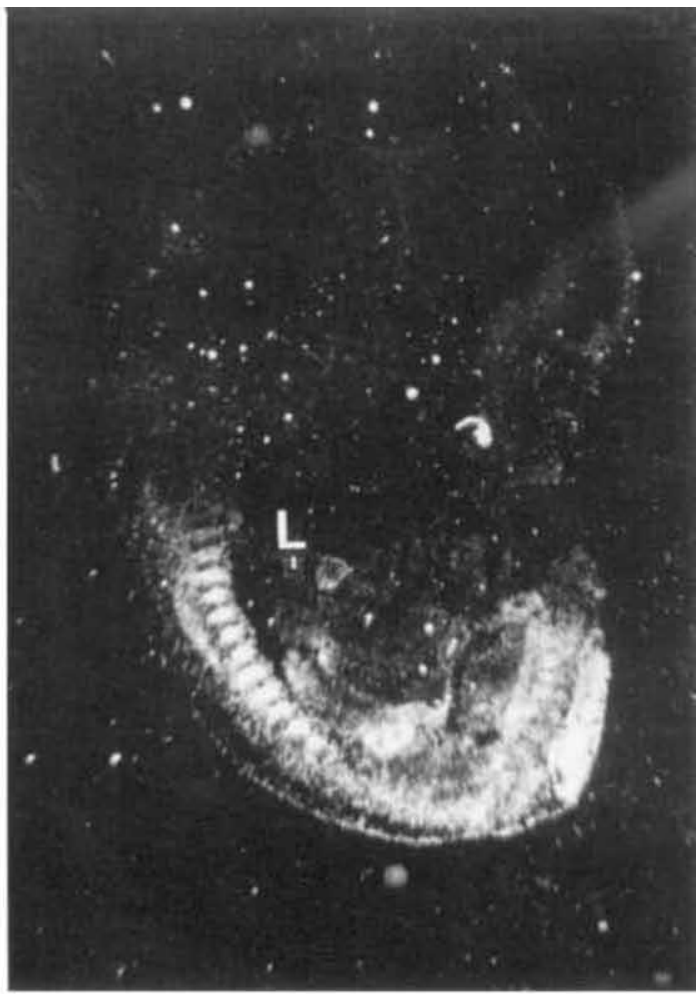

Hox 3.1

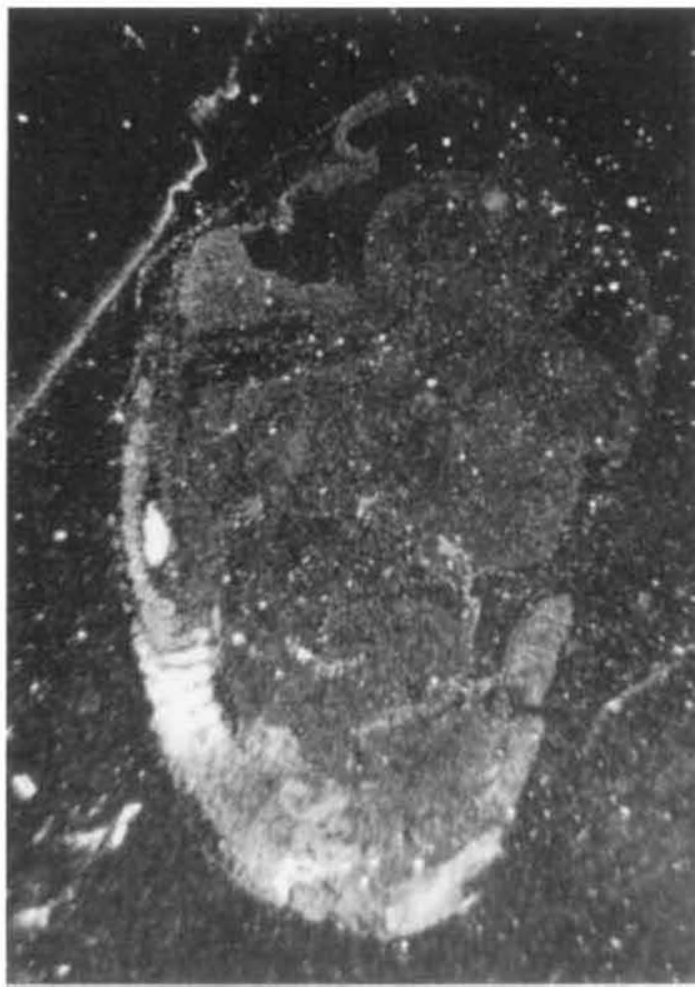

Fig. 5. In situ hybridization to parasagittal sections of 12-day embryos. Four dark-field images hybridized with the respective probes are shown. The sections hybridized with $H o x$ 1.1, 1.2 and 1.3 are serial. The section hybridized with Hox 3.1 is more medial. Indicated are the first thoracic prevertebrae $(T 1)$, the lung bud $(L)$, and the kidney $(K)$ 
Hox 3.1 Hox 1.1 Hox 1.2 Hox 1.3

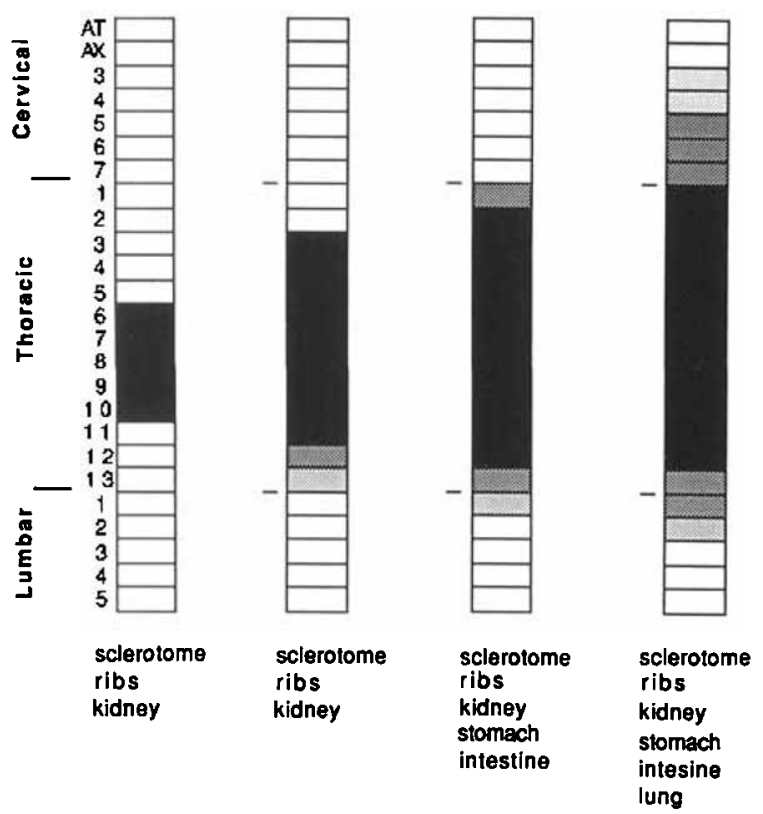

Fig. 6. A summary of in situ hybridization data obtained with 12-day embryos. The segmented vertebral column is represented by the rectangles. Segments expressing the respective Hox genes are shaded; the degree of shading approximates the relative level of transcripts detected. Other mesoderm-derived tissues that express the respective Hox gene are listed below the column

bud (as indicated in Fig. 5). Similar to the situation at 11 days of gestation, $\operatorname{Hox} 1.1$ is still more posterior than Hox 1.2. Hox 1.1 expression in mesoderm-derived tissues is limited to the metanephros, as described previously [37]. Interestingly, Hox 3.1 expression at 12 days of gestation is even more posterior, beginning at the sixth thoracic prevertebrae [5]. The Hox 3.1 gene also shows a clear posterior limit of expression at the tenth thoracic prevertebrae, as noted previously [5]. Posterior expression boundaries for $\operatorname{Hox} 1.1, \operatorname{Hox} 1.2$ and $\operatorname{Hox} 1.3$ are not as clearly defined, since the hybridization signals fade over several prevertebrae.

A summary of the expression data obtained for four Hox genes is presented in Fig. 6. This represents data obtained by serial sectioning of three different embryos at 12 days of gestation. Positive expression in prevertebrae is outlined in the shaded boxes. In addition, other mesodermderived tissues expressing the gene at 12 days of gestation are listed below. There is a clear correlation between the anterior expression limit in the vertebral column and the number of mesoderm-derived tissues that express the gene. Hox 1.3 and Hox 1.2 extend furthest anterior and are both found in numerous mesoderm-derived tissues, whereas Hox 1.1 and Hox 3.1 are more restricted. Quite strikingly, the anterior boundary of expression and the gene order along the chromosome correlate linearly. Hox 1.1 lies more $5^{\prime}$ to $\operatorname{Hox} 1.2$ and is expressed more posteriorly. Similarly, Hox 1.2 lies $5^{\prime}$ to Hox 1.3 and is expressed more posteriorly. In addition, Hox 3.1, although it is on another chromosome, belongs to a Hox subfamily that lies even more $5^{\prime}$ to Hox 1.1 [12] and is expressed even more posteriorly. It should be noted that all four of these genes are also ex- pressed in ectoderm-derived tissues, particularly the neural tube and the spinal ganglia. Although in the neural tube expression boundaries along the anterior-posterior axis are more difficult to determine, the general correlation that genes $5^{\prime}$ in the cluster are expressed more posteriorly holds true for both the Hox 1 and the Hox 2 clusters [19, 25].

\section{Discussion}

By in situ hybridization to serial sections of mouse embryos, we have shown differences in the anterior expression boundaries that correlate with the position of certain Hox genes along a chromosome. A similar principle exists in the Drosophila Antennapedia and Bithorax clusters. In the bithorax cluster (for review see [43]), the genes Ultrabithorax (Ubx), $a b$ dominal $A$ and $A b d o m i n a l-B(A b d B)$ are all transcribed in the same direction such that $A b d B$ is most $5^{\prime}$ and $U b x$ is most $3^{\prime}$. Mutations which inactivate the $A b d B$ transcript phenotypically manifest themselves more posterior than mutations in $a b d A$ or $U b x$. The mouse Hox 1 cluster also is transcribed unidirectionally such that genes expressed more posteriorly are at the $5^{\prime}$ end of the cluster. However, the genes of the Antennapedia cluster are not all transcribed in the same direction, although there is some order along the cluster that correlates with the anterior-posterior body axis (for review see [22]). Thus, the Hox genes of the mouse, whose functions remain unknown, share a revealing feature with the genes that specify position along the body axis in Drosophila. The correlations described in this report have also been noted by Gaunt et al. [19] with genes of the Hox 1 cluster and Graham et al. [24] with genes from the Hox 2 cluster.

The expression boundaries in mesoderm, although most apparent at 12 days of gestation, may already be specified at much earlier stages. In 8-day embryos, Hox 1.3 expression is detected in posterior mesoderm, whereas Hox 1.1 appears to be restricted to ectoderm and the allantois. This may reflect the timing of development such that Hox 1.1 expression is found only upon further extension of the embryonic mesoderm, at later developmental stages. Alternatively, the sensitivity of in situ hybridization is such that only peak levels of transcripts are easily detected and low levels of expression cannot be ruled out. Interestingly, Hox 1.5 expression can be detected in ectoderm and mesoderm at earlier stages $[16,17]$, compared to $H o x 1.3$ and Hox 3.1. Since Hox 1.5 is located more $3^{\prime}$ in the Hox 1 cluster and is expressed more anteriorly, we can postulate that not only does the anterior expression boundary correlate linearly with gene order along the chromosome but also the timing of transcript accumulation. Genes that are expressed more anteriorly are also expressed first. This may be inherent in the embryo since the neural tube and mesodermal plates extend posteriorly during development. Alternatively, a timing of transcriptional initiation along a cluster may be programmed by a variable response to a specific morphogen. Whether induction of Hox genes is at the level of transcription initiation in embryos is unclear, since the Hox 1.1 transcripts are induced by a posttranscriptional mechanism in F9 cells [8] whereas the Hox 1.3 transcripts are induced by increased transcription initiation in F9 cells [41]. In any event, a variable threshold response to a morphogen originating at the posterior end of the embryo, whether it activates Hox genes at the transcriptional or posttranscriptional level, makes an attractive model for in- 
duction, particularly when considering the retionic acid response of Hox genes in embryonal carcinoma cells [4].

The anterior limits of Hox gene expression patterns are most evident in the developing vertebral column. Additionally, there is a correlation between the degree of anterior expression and the number and position of other mesoderm tissues that also express a particular $\operatorname{Hox}$ gene $[9,19,37]$. This may reflect the position of origin in the lateral plate or intermediate mesoderm along the anterior-posterior axis. Anterior limits in ectoderm-derived tissues, specifically in the neural tube and dorsal root ganglia, also correlate approximately with gene order [19], although neural tube expression boundaries cannot be determined as precisely.

The Hox 1.2 gene is expressed in the kidney, stomach and intestines, but not in the lung bud. Gaunt et al. [19] detected transcripts in lung using a probe containing the Hox 1.2 homeobox and approximately 500 bp of $3^{\prime}$ untranslated sequences. It should be noted that the $3^{\prime}$ of the Hox 1.2 gene has not been determined, and such a probe could potentially hybridize to the large $4.0-\mathrm{kb}$ Hox 1.3 transcript observed at low levels [14]. Using a Hox 1.2 homeobox probe, Toth et al. [47] also did not detect lung specific transcripts. Thus, the probe used in our present study, which contains only part of the box and $1.2-\mathrm{kb}$ of upstream sequence, may more accurately reflect $H o x 1.2$ mRNA levels.

Although the developmental expression patterns of murine $H o x$ genes have received much attention and have, in part, substantiated the hypothesis that these genes are important regulatory factors, the function of murine $H o x$ genes remains unclear. Overexpression of a $H o x$ gene in transgenic mice has already provided insight into the potential role of the Hox 1.4 gene in peripheral nerve innervation [50]. Given the overlapping but unique expression patterns observed during embryogenesis, it would certainly be of interest to alter the expression domains by substituting cisacting regulatory sequences between different $H o x$ genes. Alternatively, mutation of a Hox gene by homologous recombination [51] may eventually lead to assignment of function based on mutant embryonic phenotypes. Based on the current available expression data, it is unlikely that $H o x$ genes are involved in specifying individual cell lineages, since they are expressed in many cell types. It is more likely that position along the body axis is specified, perhaps through a combinatorial effect of different Hox genes. Thus, although genetic manipulation in vivo is becoming routine, interpretations of gene function in transgenic animals with altered expression patterns of mutated genes may prove difficult because of pleiotropic effects.

Acknowledgements. We thank Carola Dony for useful discussion and Ralf Altschäffel for excellent photography. G.R.D. is an Alexander von Humboldt fellow. This research was supported by the Max Planck Society.

\section{References}

1. Akam M (1987) The molecular basis for metameric pattern in the Drosophila embryo. Development 101:1-22

2. Awgulewitsch A, Utset MF, Hart CP, McGinnis M, Ruddle FH (1986) Spatial restriction in expression of a mouse homeo box locus within the central nervous system. Nature 320:328335

3. Baron A, Featherstone MS, Hill RE, Hall A, Galliot B, Duboule D (1987) Hox-1.6: A mouse homeobox containing gene member of the Hox 1 complex. EMBO J 6:2977-2986
4. Breier G, Bucan M, Francke U, Colber-Poley AM, Gruss P (1986) Sequential expression of murine homeobox genes during F9 EC cell differentiation. EMBO J 5:2209-2215

5. Breier G, Dressler GR, Gruss P (1988) Primary structure and developmental expression pattern of Hox 3.1, a member of the murine Hox 3 homeobox gene cluster. EMBO J 7:1329-1336

6. Colberg-Poley AM, Voss SD, Chowdhury K, Gruss P (1985) Structural analysis of murine genes containing homeo box sequences and their expression in embryonal carcinoma cells. $\mathrm{Na}$ ture 314:713-718

7. Colberg-Poley AM, Voss SD, Chowdhury K, Stewart CL, Wagner EF, Gruss P (1985) Clustered homeo boxes are differentially expressed during murine development. Cell 43:39-45

8. Colberg-Poley AM, Püschel A, Dony C, Voss S, Gruss P (1987) Posttranscriptional regulation of a murine homeobox gene transcript in $\mathrm{F9}$ embryonal carcinoma cells. Differentiation 35:206-211

9. Dony C, Gruss P (1987) Specific expression of the Hox 1.3 homeo box gene in murine embryonic structures originating or induced by the mesoderm. EMBO J 6:2965-2975

10. Dressler GR, Gruss P (1988) Do multi-gene families regulate vertebrate development? Trends Genet 4:214-219

11. Duboule D, Baron A, Mähl P, Galliot B (1986) A new homeobox is present in overlapping cosmids clones which define the mouse Hox 1 locus. EMBO J 5: 1973-1980

12. Duboule D, Galliot B, Baron A, Featherstone MS (1988) Murine Homeo Genes: some aspects of their organization and structure. In: de Laat S, Bluemsuk JG, Mummery CL (eds) Cell to Cell Signals in Mammalian Development. NATO ASI Series. Springer, Berlin Heidelberg New York

13. Fainsod A, Awgulewitsch A, Ruddle FH (1987) Expression of the murine homeo box gene Hox 1.5 during embryogenesis. Dev Biol 124:125-133

14. Fibi M, Zink B, Kessel M, Colberg-Poley AM, Labeit S, Lehrach $H$, Gruss $P$ (1987) Coding sequence and expression of the homeobox gene Hox 1.3. Development 102:349-359

15. Gall J, Pardue M (1971) Nucleic acid hybridization in cytological preparations. Meth Enzymol 38:470-480

16. Gaunt SJ (1987) Homeobox gene Hox 1.5 expression in mouse embryos: earliest detection by in situ hybridization. Development $101: 51-60$

17. Gaunt SJ (1988) Mouse homeobox gene transcripts occupy different but overlapping domains in embryonic germ layers and organs: a comparison of Hox 3.1 and Hox 1.5. Development 103:135-144

18. Gaunt SJ, Miller JR, Powell DJ, Duboule D (1986) Homeobox gene expression in mouse embryos varies with position by the primitive streak stage. Nature 324:662-664

19. Gaunt SJ, Sharpe PT, Duboule D (1988) Spatially restricted domains of homeo-gene transcripts in mouse embryos: relation to a segmented body plan. Development [Suppl] 104:169-179

20. Gehring WJ (1987) Homeotic genes, the homeobox, and the spatial organization of the embryo. The Harvey Lectures, Series $81: 153-172$

21. Gehring WJ (1987) Homeo boxes in the study of development. Science 236: 1245-1252

22. Gehring WJ, Hiromi Y (1986) Homeotic genes and the homeobox. Annu Rev Genet 20:147-173

23. Graham A, Papalopulu N, Lorimer J, McVey JH, Tuddenham EGD, Krumlauf $\mathbf{R}$ (1988) Characterization of a murine homeo box gene, Hox 2.6, related to the Drosophila deformed gene. Genes Dev 2:1424-1438

24. Graham A, Papalopolu N, Krumlauf R (1989) The murine and Drosophila homeobox gene complexes have common features of organization and expression. Cell 57:367-378

25. Hart CP, Awgulewitsch A, Fainsod A, McGinnis W, Ruddle FH (1985) Homeo box gene complex on mouse chromosome 11: molecular cloning, expression in embryogenesis and homology to a human homeo box locus. Cell 43:9-16

26. Hogan B, Holland P, Schofield P (1985) How is the mouse segmented? Trends Genet 1:67-74 
27. Hogan B, Constantini F, Lacy E (1986) Manipulating the Mouse Embryo: A Laboratory Manual. Cold Spring Harbor Laboratory, Cold Spring Harbor, New York, pp 228-242

28. Holland PWH, Hogan BLM (1988) Spatially restricted patterns of expression of the homeobox containing gene Hox 2.1 during murine embryogenesis. Development 102:159-174

29. Holland PWH, Hogan BLM (1988) Expression of homeo box genes during mouse development: a review. Genes Dev 2:773-782

30. Ingham P, Howard K, Ish-Horowitcz D (1985) Transcription pattern of the Drosophila segmentation gene hairy. Nature $318: 439-445$

31. Joyner AL, Kornberg T, Coleman KG, Cox DR, Martin GR (1985) Expression during embryogenesis of a mouse gene with sequence homology to the Drosophila engrailed gene. Cell 43:29-37

32. Keynes RJ, Stern CD (1987) Somites and neural development. In: Bellairs R, Ede DA, Lash JW (eds) Somites in Developing Embryos. NATO ASI Series, Plenum Press, New York

33. Krumlauf R, Holland PWH, McVey JH, Hogan BLM (1987) Developmental and spatial patterns of expression of the mouse homeobox gene, Hox 2.1. Development 99:603-617

34. Kessel M, Schulze F, Fibi M, Gruss P (1987) Primary structure and nuclear localization of a murine homeo domain protein. Proc Natl Acad Sci USA 84:5306-5310

35. Le Mouellic H, Condamine H, Brulet $P$ (1988) Pattern of transcription of the homeo gene Hox 3.1 in the mouse embryo. Genes Dev 2:125-135

36. Levine M, Rubin GR, Tjian R (1984) Human DNA sequences homologous to a protein coding region conserved between homeotic genes of Drosophila. Cell 38:667-673

37. Mahon K, Westphal H, Gruss P (1988) Expression of homeobox gene Hox 1.1 during mouse embryogenesis. Development [Suppl] 104:187-195

38. McGinnis W, Levine MS, Hafen E, Kuroiwa A, Gehring WJ (1984) A conserved DNA sequence in homeotic genes of Drosophila, Antennapedia and Bithorax complexes. Nature 308:428-433

39. McGinnis W, Hart CP, Gehring WJ, Ruddle FH (1984) Molecular cloning and chromosome mapping of a mouse DNA sequence homologous to homeotic genes of Drosophila. Cell $38: 675-680$

40. Meijlink F, de Laaf $R$, Verrijzer $P$, Destreé $O$, Kroezen V, Hilkens J, Deschamps J (1987) A mouse homeobox containing gene on chromosome 11: sequence and tissue specific expression. Nucleic Acids Res 15:6773-6786

41. Murphy SP, Garbern J, Odenwald WF, Lazzarini RA, Linney E (1988) Differential expression of the homeobox gene Hox 1.3 in F9 embryonal carcinoma cells. Proc Natl Acad Sci USA $86: 5587-5591$

42. Odenwald WF, Taylor CF, Palmer-Hill FJ, Friedrich V, Tani M, Lazzarini RA (1987) Expression of a homeo domain protein in non-contact-inhibited cultured cells and postmitotic neurons. Genes Dev 1:482-496

43. Pfeifer M, Karch F, Bender W (1987) The bithorax complex: control of segment identity. Genes Dev 1:891-898

44. Scott MP, Carroll SB (1987) The segmentation and homeotic gene network in early Drosophila development. Cell 51:689-698

45. Scott MP, Weiner AJ (1984) Structural relationships among genes that control development: sequence homology between Antennapedia, Ultrabithorax, and fushi tarazu loci of Drosophila. Proc Natl Acad Sci USA 78:1095-1099

46. Sharpe PT, Miller JR, Evans EP, Burtenshaw MD, Gaunt SJ (1988) Isolation and expression of a new mouse homeobox gene. Development 102:397-407

47. Toth LE, Slawin KL, Pintar JE, Chi Nguyen-Huu M (1987) Region specific expression of mouse homeobox genes in the embryonic mesoderm and central nervous system. Proc Natl Acad Sci USA 84:6790-6794

48. Utset MF, Awgulewitsch A, Ruddle FH, McGinnis W (1987) Region specific expression of two mouse homeobox genes. Science 235: 1379-1382

49. Wolgemuth DJ, Viviano CM, Ginzang-Ginsberg E, Frohman MA, Joyner AL, Martin GR (1987) Differential expression of the mouse homeobox containing gene Hox 1.4 during male germ cell differentiation and embryonic development. Proc Natl Acad Sci USA 84:5813-5817

50. Wolgemuth DJ, Behringer RR, Mostoller MP, Brinster RL, Palmiter RD (1989) Transgenic mice overexpressing mouse homeobox containing gene Hox 1.4 exhibit abnormal gut development. Nature 337:464-467

51. Zimmer A, Gruss P (1989) Production of chimeric mice containing embryonic stem (ES) cells carrying a homeobox Hox 1.1 allele mutated by homologous recombination. Nature (in press)

Accepted in revised form July 22,1989 